\title{
For Love, Money and Status, or Personal Growth? A Survey of Young Emirati Women's Educational Aspirations
}

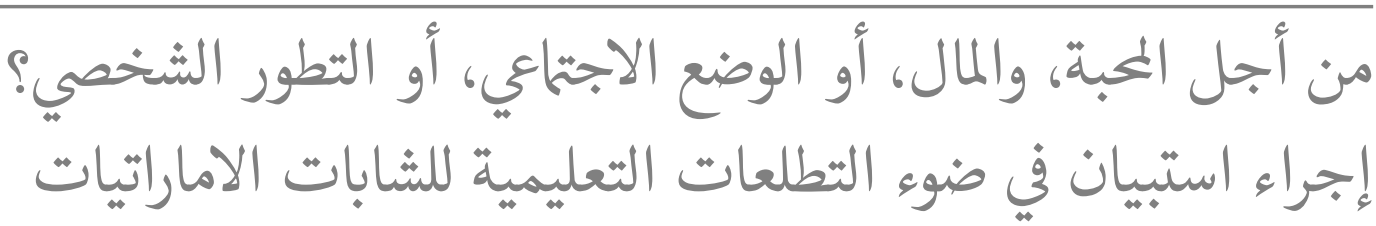

Woohyang Sim

Institute for Advanced Studies in Education, Waseda University, Tokyo, Japan

Corresponding Author:

Woohyang Sim

chloesim1007@gmail.com

Submitted: November 7, 2019

Accepted: December 18, 2019

Published: July 29, 2020

Production and Hosting by Knowledge E

(c) Woohyang Sim. This article is distributed under the terms of the Creative Commons

Attribution License, which permits unrestricted use and redistribution provided that the original author and source are credited.

Managing Editor:

Natasha Mansur

\section{Abstract}

The United Arab Emirates has been in the spotlight in recent years in light of its rapid growth and development. A key area of interest is the expansion of education, especially higher education for women, which has witnessed enormous growth in the last decade. However, despite the rapid increase in female higher education enrollment, women's labor participation remains low, leading to questions on why highly educated young women are not in employment. This study investigates the incongruence between the growth of female attainment of higher education and women's career inactivity over the last decades. To explore this mismatch, the study examines Emirati women's perception of the role of higher education, analyzed through examining their educational and career aspirations and the correlations between these two. The study finds that for Emirati women, education is not always a means to an end, but simply the end itself. For some women, education is related to supplementing personal growth and contentment. The findings suggest that Emirati women aspire to further their education, especially through earning doctorate degrees. However, they do not necessarily connect their education to their intended future occupation. The findings provide an alternative explanation of the disconnect between women's educational outcomes and labor market participation and provide insight into Emirati women's choice to remain unemployed.

| 1المالخصن

لقد كانت دولة الإمارات العربية المتحدة في دائرة الضوء خلال السنوات الأخيرة في ضوء نموها السريع وتطورها. أحد مجالات الاهتام الرئيسية الخاصة بها هي

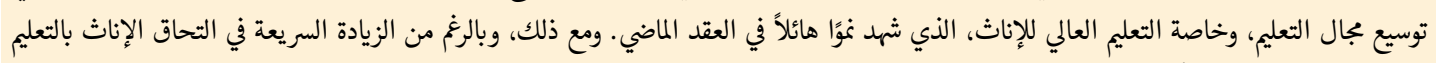

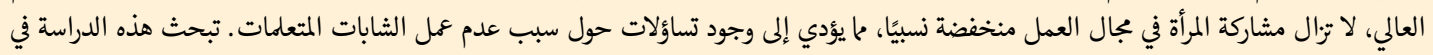

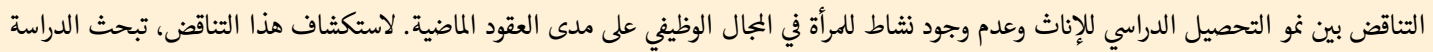



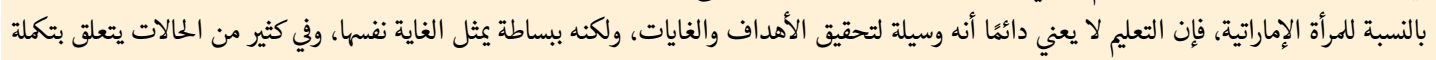

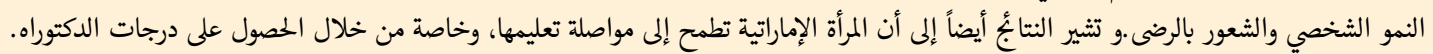

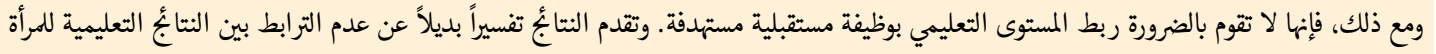



Keywords: Educational aspiration, Labor participation, UAE Women, Education, and Labor Force Mismatch الكالمات المفتّاحية؛ التطلعات التعليمية، مشاركة الفئة العاملة، عدم تطابق التعليم وقوى الفئة العاملة 


\section{Rapid Expansion of Higher Education}

The higher education sector in the United Arab Emirates (UAE) has experienced enormous growth. The decades following the nation's independence, characterized by the oil boom, witnessed rapid higher education expansion in "one generation" (Mahdi, 1997, p. 21). In 1990, only five higher education institutions existed in the UAE. By 2018,76 such institutions have been founded and more are in the process of being established (United Arab Emirates Ministry of Education, 2018). These 76 higher education institutions offer over 80 accredited programs. With the increase in the number of institutions and program offerings, enrollment in higher education has increased sharply.

Emirati females have had access to free state higher education since 1977, less than seven years since the founding of the UAE (Findlow, 2007). Yet, during these early years, social conditions including segregated and unequal education and social constraints have at times perceived the goals of education for females to be limited to teaching children at home or professionally (Findlow, 2007). However, in recent decades, females have equal access to a wide variety of fields of study. Moreover, the achievement gap highlights that Emirati women enrolled in higher education perform at a level equal or superior to their male counterparts. For example, looking at students enrolled in UAE's government higher education institutions in 2016/17 (Table 1), by field of study, women outnumber men in all majors except engineering. Table 1 also shows the corresponding gender divide in higher education in the country. Total of 43,128 students in UAE government higher education institutions, of which $74 \%$ of students were female, while only $26 \%$ were male.

To increase the nation's international competitiveness through raising human capital, the UAE government has made education a top priority in the development strategy of the UAE government (Department of Economic Development [DED], 2016). As part of this strategy, the UAE government has promoted higher education, devoting a large share of the national budget to the sector. ${ }^{1}$ The aim of this large financial injection was to support higher education and its crucial role in economic development. Tertiary education can lead to an accelerated path to skilled knowledge-based employment and economic development (Shihab, n.d.). In response to this, employability development programs, such as the World of Work (WOW) program, have been implemented in UAE higher education institutions to provide university students opportunities to develop employability skills (El-Temtamy et al., 2016).

\section{Low Women's Labor Force Participation}

Despite the rapid expansion of higher education in the UAE due to the government's extensive efforts, a mismatch between educational achievement and labor participation has existed, especially for females. This mismatch has been identified and questioned for over a decade, both by researchers and policymakers inside and outside of the country (see Alkhabeer Capital, 2013; AON Hewitt, 2012; Bhayani, 2014; ILO, 2015; IMF, 2014; Jelili, 2010; Kabbani \& Kothari, 2005; Gonzalez et al., 2008; Oxford Strategic Consulting, 2010; Ridge, 2014; Gonzalez et al, 2008; World Economic Forum, 2014). The 


\section{Table 1}

Total number of students at UAE government higher education institutions by field of study (2016/17)

Field of study
Arts \& Design
Engineering
Information Technology
Business \& Economics
Education
Sciences
Foreign Languages
Environment \& Health Sciences
Medical Sciences
Communication \& Media Sciences
Sharia \& Law
Human \& Social Sciences
Food \& Agriculture
Foundations
Undeclared major
Total

\begin{tabular}{|c|c|c|}
\hline & UAE National & \\
\hline Male & Female & Total \\
\hline 0 & 652 & 652 \\
\hline 4,269 & 3,477 & 7,746 \\
\hline 1,343 & 3,191 & 4,534 \\
\hline 2,177 & 7,219 & 9,396 \\
\hline 1 & 1,515 & 1,516 \\
\hline 31 & 630 & 661 \\
\hline 0 & 258 & 258 \\
\hline 170 & 1,772 & 1,942 \\
\hline 46 & 129 & 175 \\
\hline 259 & 2,307 & 2,566 \\
\hline 225 & 542 & 767 \\
\hline 269 & 3,949 & 4,218 \\
\hline 23 & 332 & 355 \\
\hline 2,256 & 5,650 & 7,906 \\
\hline 97 & 339 & 436 \\
\hline $11,166(26 \%)$ & $31,962(74 \%)$ & $43,128(100 \%)$ \\
\hline
\end{tabular}

Note. Adapted from United Arab Emirates Ministry of Education, Federal Competitiveness and Statistics Authority, 2018. Available from https://fcsa.gov.ae/en-us/Pages/Statistics/Statistics-by-Subject.aspx In the public domain.

issue is particularly notable in the case of women. In the UAE, women represent about $70 \%$ of higher education students (see Table 1, above), but their labor participation rate (34\%) has remained low relative to men (63\%) in 2014. In Figure 1, we see that women's labor force participation in the UAE has increased slightly, although we know that enrollment in higher education has increased more during the same period.

Low labor force participation among highly educated women is a key social issue, not only in the UAE, but across the world (AON Hewitt, 2012; Bahira, 2003; ILO, 2015). However, in the case of the Gulf Cooperation Council (GCC) countries, including the UAE, women have completed more years of higher education than men, yet do not benefit in terms of higher rates of employment. In fact, these women are actually more likely to be unemployed than women who possess only a primary education or less (ILO, 2015; Ridge, 2014). The low employment rate of university educated women continues despite the country's economic strength and an active Emiratization employment policy ${ }^{2}$ for nationals (Modarress, Ansari, \& Lockwood, 2013). Theoretically, these policies ought to create and secure public and private sector jobs for both genders (Zeffane \& Kemp, 2012) 


\section{Figure 1}

Labor participation rate by age 1990-2019 (modeled ILO estimate)

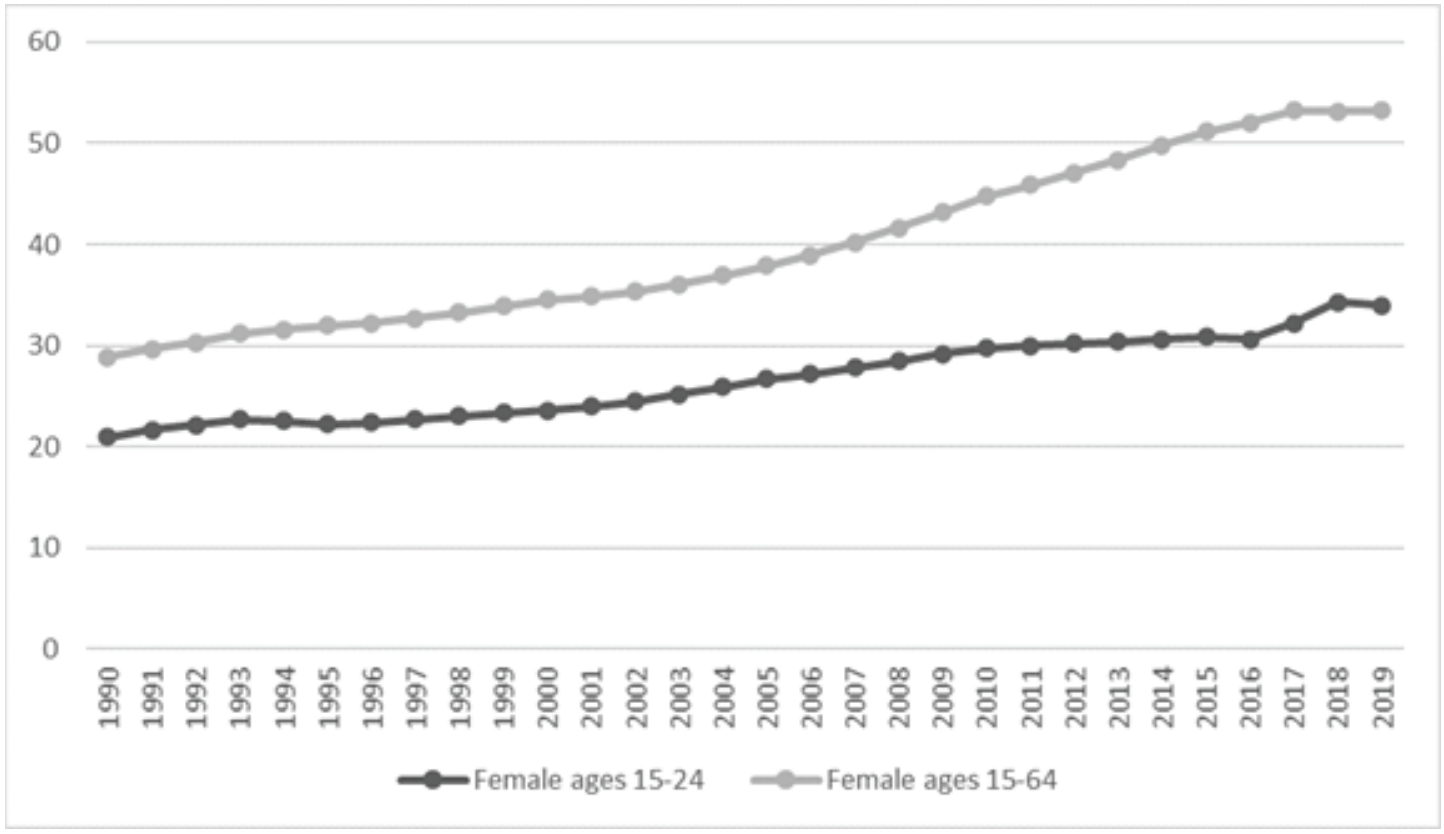

Note. Adapted from International Labour Organization, ILOSTAT database, by World Bank, 2020, (https://data.worldbank.org/indicator/). In the public domain.

\section{Disconnect between Academic Success and Employ- ment of Women}

The effect of rising enrollment in education usually corresponds with a rise in the female labor force (Verick, 2014). However, this effect is not seen in the UAE. Based on these two conflicting trends regarding the Emirati women, research focusing on either education or the labor market, or both, in the Gulf has recently been actively pursued by scholars. Although this article does not address issues of gender equality, it is set against a background of the international interest in human rights and the empowerment of women in the region, particularly including research questioning the reasons behind the high unemployment rate of highly educated women. For instance, Young (2017) notes that the likelihood for being unemployed is much greater for young women who have attained graduate or post graduate degrees in the region, and argued that the educated woman -as human capital- is not being utilized to its full potential. Regarding low labor force participation, Alkhabeer Capital (2013) argues that the low participation rates of women in the labor force is due to the probable restrictions imposed by the "cultural and value system" on women's work in "certain domains," although they do not elaborate on the factors which are adversely affecting female labor outcomes (p. 7). Others argue that the low labor participation rates are due to a clash between Islamic culture and the West, the so-called, "clash of civilizations'3 (Inglehart \& Norris, 2003). However, the causal relationship between religion and people's code of behavior has not been fully established. If labor non-participation is a result of a conflict with Western 
civilization, it is difficult to explain women's participation in education, which arguably demonstrates acceptance of the Western educational system.

Literature that explains the possible reasons behind the low labor participation rates of women in the UAE focuses on unemployment in the labor force. AON Hewitt (2013) found that the problems of students' attitude, preferences, aptitudes, and values regarding employment could be due to what has become known as the rentier mentality. According to Beblawi \& Luciani (1987), the rentier mentality means receiving income or wealth due to chance or situation, not for the price for labor. Indeed, as one of the representative countries known as a rentier state, the UAE government solidifies UAE citizens' economic stability and social well-being through the social welfare system (Alhejji, \& Garavan, 2016).

However, the rentier mentality only provides limited explanation as a reason for unemployment in the labor force. Distinguishing between those who are 'unemployed in the labor force' and 'unemployed and not in labor force' is of enormous importance in order to understand the labor situation of women in the Gulf. Undoubtedly, women's labor force participation in the region is low, but their unemployment rate is even lower in general. For instance, in Dubai, the unemployment rate of women is only 4 percent, ${ }^{4}$ but only 35.5 percent of women are participating in the labor force (Dubai Statistics Center, 2014; OECD, 2016). These two numbers - 35.5 and 64.5 - are particularly important to grasp the larger issue. First, of the 35.5 percent of women, aged 15 and over, who are "able to work" and are "willing to work," 96 percent of them successfully participate in the labor market, and only 4 percent remain unemployed. Second, the remaining 64.5 percent of women capture all those who are not in the labor force. This encompasses both women who are "unable to work" but also those who "choose not to work". Thus, the issue appears to be one of non-labor force participation or voluntary unemployment. People who are educated are choosing not to work. Despite this fact, and problematically, the question of why educated women cannot enter the labor-market is still examined through discourses with the underlying assumption that GCC women pursue higher education primarily to secure employment.

Despite a steady rise in interest in women's higher education in the UAE, and the Gulf region in general, over the past decade, scant literature exists on the educational aspirations or motivations of women from the region. Findlow (2007) revealed that Emirati women see labor participation as a matter of choice, considering higher education as an efficient, open-ended tool. Comparable results were obtained from recent research on educational aspirations in Saudi Arabia. Sim (2016) found gender differences in educational aspiration among young Saudi men and women. Males expected economic outcomes from education, while females expected self-improvement that aids societal development. In context of this research, the Western perspective's predominant observation on GCC women seems to be far from the actual situation (Alwedinani, 2016). This necessitates a more sophisticated, multivariate explanation for women's higher educational choices in this region, which is presented in this article. 
Figure 2

Labor force status

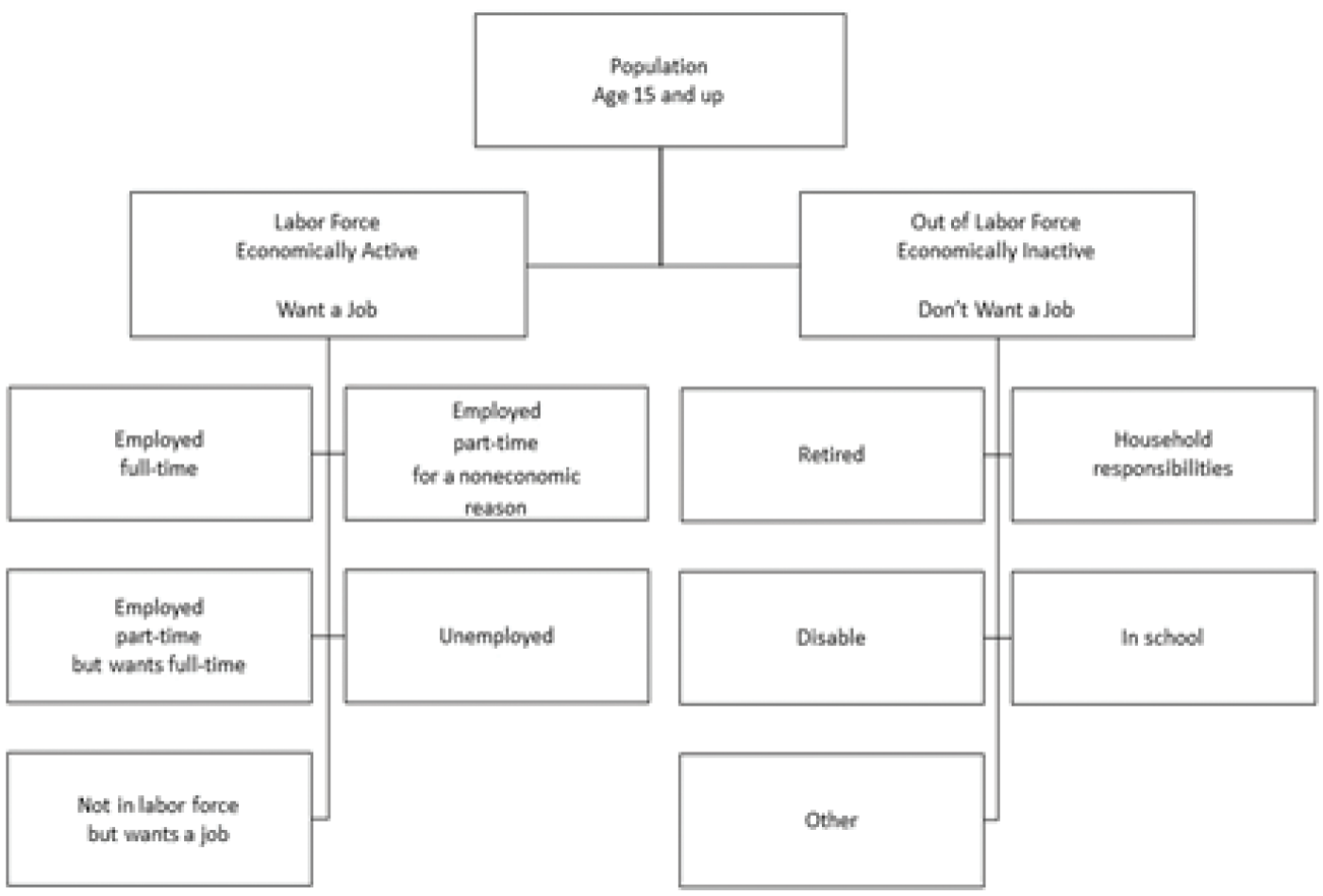

Note. Adapted from The ZPOP Ratio: A Simple Take on a Complicated Labor Market, by Federal Reserve Bank of Atlanta, 2015. (https://www.frbatlanta.org/blogs/macroblog/2015/09/22/

the-zpop-ratio-a-simple-take-on-a-complicated-labor-market.aspx). In the public domain.

\section{Research Questions}

This article is based on research conducted in the UAE which explores both Emirati women's educational aspirations and the reasons behind them in relation to their career aspirations. This article is guided by the following questions:

1. Why do Emirati women pursue higher education?

2. What career aspirations do Emirati women have?

3. Do Emirati women relate their education to an occupation or career?

\section{Methodology and Description of Respondents}

This paper is based on research conducted in 2016. For the study, an online questionnaire was distributed between January and October 2016. The survey was conducted in Arabic. A total of 2,573 people responded to the survey. Excluding non GCC-nationals, male respondents, and those who responded to less than $50 \%$ of the survey, data from a total of 1,604 GCC national women were collected. Excluding other GCC national women, data from 161 UAE national women aged between 15 to 30 years was analyzed using IBM SPSS Statistics 24. The pattern matrix of a rotated principal component 
analysis was applied to create composite measure by summing the 9 items asking why participants sought higher education.

This study is not without limitations. The survey analysis excluded middle-aged and elderly woman who are less familiar with online questionnaires. As the findings do not focus on the extent that Emirati women's educational and career aspirations may be systematically different depending on the age group, the results of this study are not generalizable to all age groups of Emirati women.

Table 2 provides a description of respondents, including age, current employment status, economic status, and parental education level. In addition, survey data was collected using a snowball sampling method, and the questionnaire did not include any identifiable confidential information. This sampling method is based on referrals from initial participants or assistants to generate additional participants (Dudovskiy, 2018). Thus, it was particularly important to select sources who could spread the URL of the online questionnaire. The survey URL of the online survey was spread through e-mail and social networking services (SNS) to university professors, education officials, researchers, and university students. The online community of each country was leveraged to share the questionnaire through multiple referrals. To prevent unintentional participation in the survey, the preface of the survey underlined the opt-out opportunity. Thus, receipt of responses from the candidates were considered as consent from the respective participants. Moreover, the online survey and the web flyer requesting interviews provided full information about the study.

\section{Findings}

The study participants' responses thus suggest that at least some UAE women have high educational aspirations. Of the 136 respondents to the question on current and future education aspirations, 103 (75.7\%) reported that they want to obtain an advanced degree from a higher education institution. Moreover, 57 (55.3\%) women stated that they want to obtain a doctorate.

In addition, the findings suggest that high educational ambitions of contemporary Emirati women may be passed onto their children (Table 4). All respondents wanted their children to complete at least undergraduate studies, and more than $75 \%$ also expected their children to gain doctoral degrees, regardless of the child's gender.

Considered in tandem, these results suggest that Emirati women generally have a strong educational aspiration to gain advanced academic degrees. Even when compared to Japan and Korea, whose societies place a significant value on education, Emirati women show higher educational expectations. Among 3,961 Japanese college students, only 7 percent wished to pursue a doctorate and 25 percent a master's degree. Among 835 Korean college students, only 3.3 percent wished to pursue a doctorate degree and 7.1 percent chose a master's degree as their desired educational degree (Yamada, 2007; Shin, Hwang, \& Jo, 2015, p. 58). 
Table 2

Description of respondents

\begin{tabular}{|c|c|c|c|}
\hline \multirow[t]{3}{*}{ Age $(n=161)$} & $15-19$ & \multicolumn{2}{|c|}{$56 \%(n=90)$} \\
\hline & $20-24$ & \multicolumn{2}{|c|}{$39 \%(n=63)$} \\
\hline & $25-30$ & \multicolumn{2}{|c|}{$5 \%(n=8)$} \\
\hline \multirow[t]{3}{*}{ Current status ( $n=161)$} & Student & \multicolumn{2}{|c|}{$91 \%(n=147)$} \\
\hline & Employed & \multicolumn{2}{|c|}{$4 \%(n=6)$} \\
\hline & Unemployed & \multicolumn{2}{|c|}{$5 \%(n=8)$} \\
\hline \multirow[t]{5}{*}{ Economic status $(n=131)$} & Rich & \multicolumn{2}{|c|}{$42 \%(n=55)$} \\
\hline & Relatively Rich & \multicolumn{2}{|c|}{$33 \%(n=43)$} \\
\hline & Average & \multicolumn{2}{|c|}{$24 \%(n=32)$} \\
\hline & Somewhat Poor & \multicolumn{2}{|c|}{$1 \%(n=1)$} \\
\hline & Poor & \multicolumn{2}{|c|}{$0 \%(n=0)$} \\
\hline \multirow[t]{5}{*}{ Parental education level $(n=136)$} & & Father & Mother \\
\hline & Primary or below & $16 \%(n=22)$ & $23 \%(n=31)$ \\
\hline & Secondary & $45 \%(n=61)$ & $43 \%(n=59)$ \\
\hline & $\begin{array}{c}\text { College / Undergraduate } \\
\text { University }\end{array}$ & $27 \%(n=37)$ & $26 \%(n=35)$ \\
\hline & Graduate or Higher & $12 \%(n=16)$ & $8 \%(n=11)$ \\
\hline
\end{tabular}

Note. While it is common to directly ask about annual income in questionnaires to measure socioeconomic status, this study investigated social economic status through leading questions using a rating scale of 5 , ranging from Rich to Poor.

Table 3

Current and future educational status

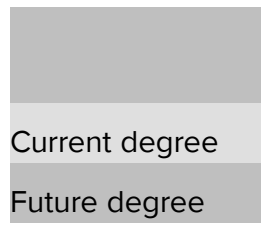

$\begin{gathered}\text { High School and } \\ \text { below }\end{gathered}$
$4 \%$
$0 \%$

\begin{tabular}{|c|}
\hline Diploma \\
\hline $8 \%$ \\
\hline $2 \%$ \\
\hline
\end{tabular}

\begin{tabular}{|c|}
\hline Bachelor \\
\hline $82 \%$ \\
\hline $23 \%$ \\
\hline
\end{tabular}

\begin{tabular}{|c|}
\hline Master \\
\hline $5 \%$ \\
\hline $34 \%$ \\
\hline
\end{tabular}

\begin{tabular}{|c|}
\hline Doctorate \\
\hline $1 \%$ \\
\hline $42 \%$ \\
\hline
\end{tabular}

Total (n)

$100 \%(136)$

$100 \%(136)$

\section{Table 4}

\section{Expected educational background of respondents for their children}

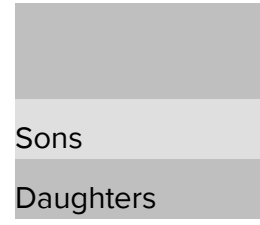

\begin{tabular}{c}
$\begin{array}{c}\text { Secondary or } \\
\text { Equivalent }\end{array}$ \\
\hline $0 \%$ \\
\hline $0 \%$ \\
\hline
\end{tabular}


Master
\begin{tabular}{l}
$13 \%$ \\
$15 \%$ \\
\hline
\end{tabular}

Doctorate
$\begin{aligned} & 80 \% \\ & 75 \%\end{aligned}$

Total (n)

$100 \%(136)$

$100 \%(136)$ 


\section{Why do Emirati Women Pursue Higher Education?}

Why then do Emirati women particularly show a strong passion for advanced - more specifically, doctoral - degrees? Table 5 shows results from a principal component analysis of various motivational factors in seeking higher education. The survey respondents rated 14 statements using a 4-point scale ranging from "strongly agree" to "strongly disagree". Five variables with low communalities -less than 0.50 - were excluded because they did not contribute significantly to measuring the underlying components. Figure 3 shows four extracted components, which are labeled "Career-minded reasons" (Component 1, $\alpha=.821$ ), "Family related reasons" (Component 2, $\alpha=.761$ ), "Social environment related reasons" (Component $3, \alpha=.562$ ) and "Personal growth reason" (Component 4).The four synthetic variables were created by computing an average of the items that make up each component. However, as there was only one item that made up the "Personal growth reason" component, an average was not computed for it.

\section{Table 5}

The principal component analysis and purpose for attending university

\begin{tabular}{|c|c|c|c|c|}
\hline & \multicolumn{4}{|c|}{ Component } \\
\hline & 1 & 2 & 3 & 4 \\
\hline To obtain a higher salary job & 0.91 & 0.08 & 0.08 & 0.00 \\
\hline $\begin{array}{l}\text { To achieve a job with a higher social } \\
\text { status }\end{array}$ & 0.85 & 0.07 & 0.08 & 0.09 \\
\hline To be eligible for a job & 0.78 & 0.11 & 0.02 & 0.03 \\
\hline To respond to expectations of my family & 0.09 & 0.90 & 0.06 & -0.01 \\
\hline To match my family's social status & 0.13 & 0.87 & 0.12 & 0.02 \\
\hline To form friendships & 0.05 & 0.12 & 0.79 & -0.01 \\
\hline To enjoy university life & 0.11 & -0.01 & 0.76 & 0.29 \\
\hline Didn't have anything else to do & 0.02 & 0.18 & 0.58 & -0.49 \\
\hline To develop personal values & 0.09 & 0.06 & 0.14 & 0.88 \\
\hline Factor Contribution & 2.20 & 1.64 & 1.60 & 1.10 \\
\hline Cumulative Contribution Rate & 24.49 & 42.70 & 60.49 & 72.70 \\
\hline \multicolumn{5}{|c|}{ Principal Component Analysis, Varimax rotation used } \\
\hline \multicolumn{5}{|c|}{ Kaiser-Meyer-Olkin $=.658 p<.001$} \\
\hline \multirow[t]{4}{*}{ Factor Correlation } & & $.184^{* *}$ & $.244^{* *}$ & $.176^{* *}$ \\
\hline & $.184^{* *}$ & & $.077^{* *}$ & $.102^{* *}$ \\
\hline & $.244^{* *}$ & $.077^{* *}$ & & $.223^{* *}$ \\
\hline & $.176^{* *}$ & $.102^{* *}$ & $.223^{* *}$ & \\
\hline
\end{tabular}

When the survey respondents were asked about their main purpose for pursuing higher education, the most common response was personal growth, with about 100 percent of the respondents either strongly agreeing or agreeing, of which 66 percent responded that they strongly agree. Career-minded reasons came second, with about 
77 percent either strongly agreeing or agreeing. Of this, 31 percent responded that they strongly agree. In contrast, most respondents disagreed with the two other reasons, "Family related reasons", and "Social environment related reasons." The most important implication of this result is that personal growth reason was found to be more important to the respondents than career-related reasons.

\section{Figure 3}

Purpose for attending university for women in the UAE



Also, these two reasons for seeking higher education were not mutually exclusive. When I examined the percentage of women who reported that both career and selfgrowth were important, I found that the respondents who either agreed or strongly agreed with both components accounted for the largest share of 80 out of 102 people, which is about 78.4 percent of the entire sample. This finding presents an interesting phenomenon that Emirati women's ardent desire for higher educational qualification is primarily based on personal growth.

In addition, the survey also asked a question on whether the respondents saw a specific relationship between academic achievement and marriage. Emirati women perceived that obtaining an advanced degree might not necessarily lead to a favorable marriage. Previous research has already shown that the bride-price increases as a woman's education increases; thus, well-educated women were penalized in the traditional GCC marriage market as men were unwillingly pay the high bride-prices, at times seeking foreign brides (Findlow, 2007, p. 66). Of the 130 respondents who answered this question, only 10.7 percent agreed or strongly agreed with the statement that "attending university and earning a degree is advantageous for marriage." Thus, 89.3 percent of respondents disagreed, and among these, 53.1 percent strongly disagreed (Table 6). The socio-cultural context of UAE may help to explain the mismatch between the current findings and those of previous research. More research is required into 
gender dynamics in the UAE to tease out the relationship between women's and men's education levels and marriages.

\section{Table 6}

Higher education is advantageous for marriage (\%)

\begin{tabular}{|l|c|c|c|c|}
\hline Strongly disagree & Disagree & Agree & Strongly agree & Total $(n)$ \\
\hline 53.1 & 36.2 & 9.2 & 1.5 & $100.0(130)$ \\
\hline
\end{tabular}

\section{What career aspirations do Emirati women have?}

Counter-intuitively to the reality that the Emirati women are under-represented in labor force, survey respondents reported that they have career aspirations in pursuing their intended career paths. As shown in Table 4, the survey data revealed that almost all respondents plan to pursue some form of a career after finishing their undergraduate degrees, while only 1.4 percent choose to be housewife.

However, interestingly, despite the wide-spread penchant to pursue doctorate degrees, Emirati women show limited interest in pursuing academic professions such as a college professor or a researcher although almost half of them reported that they plan to pursue doctorate degrees (see Table 3 and Table 7). In addition, other chosen, intended careers also do not seem to necessarily require a master's degree or higher, compared with their strong desire for an advanced degree.

Moreover, the percentage of UAE nationals employed as university faculty remains at low levels. Total of the 2,964 faculty members at the UAE federal higher education institutions, only 11.1 percent were UAE nationals in 2017 (Ministry of Education). This finding suggests that relatively fewer UAE nationals who hold doctoral degrees actually pursue jobs in academia despite the wide-spread penchant to pursue doctorate degrees.

\section{Do Emirati women relate their education to an occupa- tion or career?}

To better understand Emirati women's motivation for education, this study examined the relationship between the survey respondents' chosen academic majors and their intended careers in the future. As shown in Figure 4, about 28 percent of those who said they wanted to become medical professionals majored or specialized in arts and design. Furthermore, about 22 percent of those who majored in the medical sciences chose architect or urban planner as their future occupation (see Appendix $A$ for the expanded table).

This study found a mismatch between what women in the UAE study in higher education and what they would need to study to meet the qualifications necessary to enter their desired profession. While it is common to pursue careers outside of one's educational background in general, it is nearly impossible to pursue careers in 
Table 7

UAE women's chosen future career $(n=138)(\%)$

Accountant or Actuary
Architect or urban planner
Artist, designer, actor, or entertainer
Government or public company employee
Private company employee
High-ranking government official
Business executive
Business owner or proprietor
Imam ${ }^{5}$
College Professor / Scientific researcher
Computer programmer or analyst / Engineer
Homemaker / housewife
Lawyer (attorney) or judge
Military service
Medical professionals
School teacher
Social welfare or recreation worker
Translator or interpreter
Total Journalist

\begin{tabular}{|c|c|}
\hline 2.2 \\
\hline 5.8 \\
\hline 1.2 \\
\hline 10.9 \\
\hline 1.4 \\
\hline 10.9 \\
\hline 0.7 \\
\hline 8.0 \\
\hline 1.4 \\
\hline 10.9 \\
\hline 11.6 \\
\hline 1.4 \\
\hline 1.4 \\
\hline 3.6 \\
\hline 10.9 \\
\hline 5.1 \\
\hline 2.9 \\
\hline 2.9 \\
\hline 0.7 \\
\hline 100 \\
\hline
\end{tabular}

Note. The percentage of majors that do not correspond to desired profession is composed of related occupation (see details in Appendix 1): Architect or urban planner and Artist, Designer, Actor or entertainer and Government or public company employee (Arts and Design), Architect or urban planner, College Professor / Scientific researcher, Computer programmer or analyst / Engineer (Engineering), Government or public company employee, Business executive, Business owner or proprietor (Business Administration), College Professor / Scientific researcher and Medical professionals (Medical Sciences), Artist, Designer, Actor or entertainer and Government or public company employee (Mass Communication and Public Relations), Government or public company employee, Private company employee.

specialized fields such as medicine without receiving years of specific training for the practice. In other words, the survey results reveal the presence of a 'skills gap', which had been cited for many years as one of the main contributors to youth unemployment and job unpreparedness in the Arab world (EY, 2015). Moreover, the finding also suggests that the reason for the skills gap may be interpreted as due to the weak awareness of the correlation between education and occupation among UAE nationals. 


\section{Figure 4}

Major in university and percentage of majors that do not correspond to desired profession

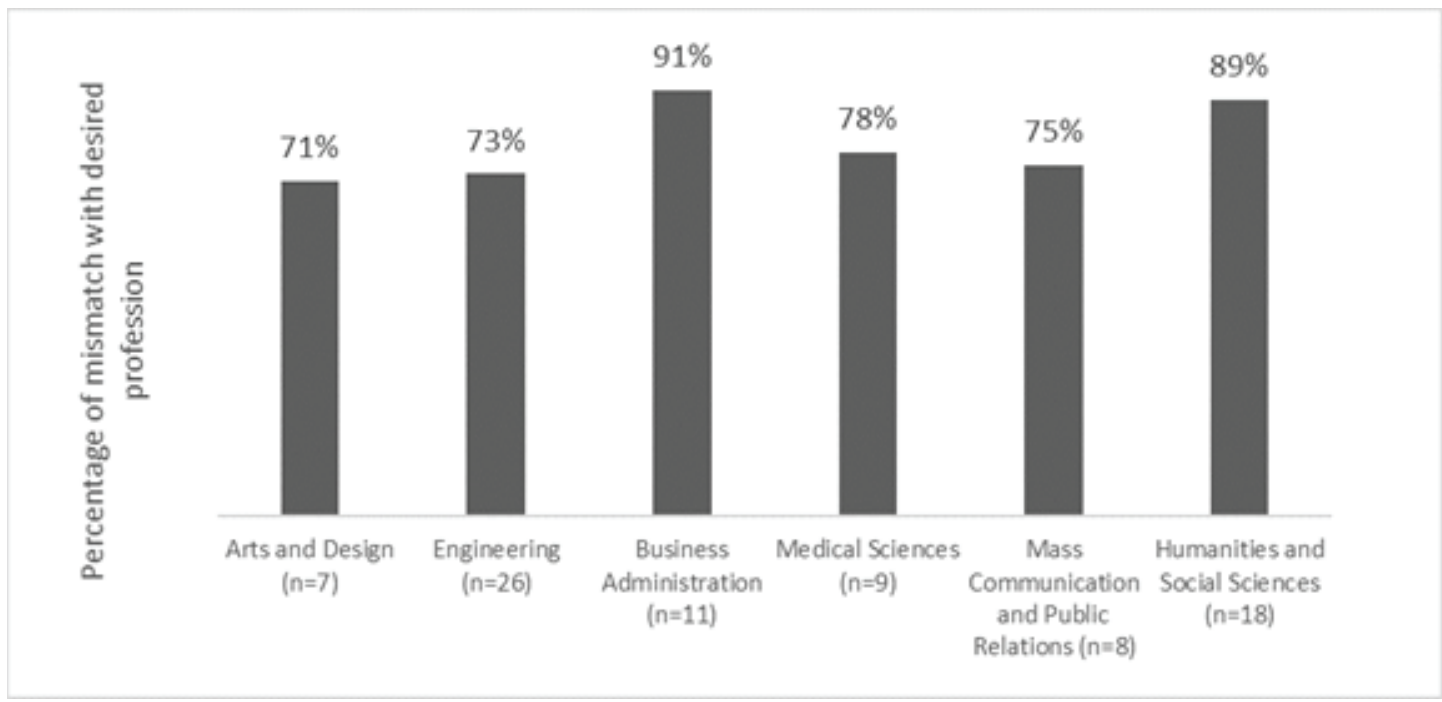

\section{Conclusion and Recommendations for Further Research}

In answering the question of why women choose to go through higher education and the reasons behind, the study produced four main findings. The first is that Emirati women have a strong desire to obtain advanced degrees, especially doctorate degrees. The second finding suggests that although career-minded reasons were a frequently selected reason in surveys for pursuing higher education, the most prevalent purpose is personal growth reason, although, thirdly, most young Emirati women wished to have a job after finishing their education. Fourthly, there was a severe mismatch between survey respondents' chosen academic majors and their intended careers. These findings, while not necessarily nationally representative, provides important insight into the mismatch between education aspirations, achievement, and labor participation by women in the UAE.

The findings indicate that the reason Emirati women pursue a higher academic degree is not necessarily to obtain a job. A mismatch between survey respondents' chosen academic majors and their intended careers not only provides a sufficient explanation for the presence of a 'skills gap', but also shows that they do not go to college or plan to acquire advanced degrees with a solid career in mind. Considering the survey results obtained, the reason for attending university is assessed differently than in other countries. For example, in South Korea, where the higher education enrollment rate is one of the world's highest at 67.6 percent in 2018, half of high school seniors said they would go to college to get a job (Choi, 2016). However, in the case of the UAE, while personal growth along with career-minded purpose leads women to university and to pursue advanced degrees, it seems they do not take concrete steps to make their career an achievable reality. Consequently, it may be inferred from the results that 
respondents do not consider a higher education degree, no matter what that higher degree is, as a tool or ticket to greater participation in the labor market.

Moreover, this study's results negate the hypothesis that highly educated Emirati women cannot participate in the labor force because of social or cultural restrictions. This finding is consistent with the finding by studies from inside the region revealed that GCC women's work force decision were made for reasons other than financial outcomes; contentment and social contribution were more important factors (Dubai Women Establishment, 2009; 2012) and also in line with those from Findlow (2007), who argues that Emirati women regard going to university "as a more productive way of spending time that also usefully keeps options open" (p.65). The presented findings indicate an interplay of a complex set of reasons that may contribute to Emirati women's educational decisions. These reasons include a knowledge and skills gap that has been examined through previous research. Furthermore, beyond the skills gap, the different social roles of higher education also have a considerable influence on women's participation. For example, attaining an academic degree may also fulfill the values of the rentier society which include expressing their social status. Lastly attaining an academic degree without the need to work exemplifies the structure of the rentier society. In contrast to previous findings which suggested tradition and culture plays a role in women's low labor participation, this paper's findings imply that tradition and culture may not inhibit women's labor participation as much as their own reasons for education attainment including personal contentment.

This study reveals a weak awareness of the correlation between education and occupation among Emirati women. The mismatch may be attributed to the relatively new education systems, which have proven limited adaptability to the drastic changes in the labor market. A lack of relevant career support systems designed to assist individual needs exacerbates the problem. Thus, an excess of graduates exists in fields not needed by the economy. Future policy makers must consider that Emirati women prize developing their personal value by studying and earning an advanced degree. However, aspirations for education - by choice - do not necessarily lead to subsequent employment.

In sum, the findings from this study further support the idea that for Emirati women, education and career were not a means to an end, but simply an end in itself, related more to personal contentment than anything else. Perhaps this line of thinking is a product of economic stability and job security afforded to UAE nationals under their social contract with their states, which may have influenced Emirati women to see a career as an option rather than a necessity. Although the changes in terms of higher education in the UAE in the past two or three decades have been breathtaking in their range and impact, women's reasons for not participating in the labor market has remained similar in over 20 years (Findlow, 2007).

Although this study is limited in its scope to empirically examine the actual educational aspirations and motivations of Emirati women through a representative survey, the findings provide compelling explanations for better understanding women's labor participation rates in the UAE. More research is needed on the educational and career 
decision making processes, and their determinants, of young Emirati and other GCC women.

\section{Funding Information}

The study was funded by the JSPS KAKENHI (grant number 18H05752, 19K14134), and supported by the Sheikh Saud bin Saqr Al Qasimi Foundation for Policy Research.

\section{Competing Interests}

The author declares that she has no conflict of interest.

\section{Biography}

Dr. Woohyang (Chloe) Sim is currently working as a researcher in the Institute for Advanced Studies in Education, Waseda University, Japan. She earned her PhD degree in Education from Waseda University, Tokyo, Japan. Her PhD dissertation, entitled What is Higher Education For? Educational Aspirations and Career Prospects of Women in the Arab Gulf, was focused on social aspects of higher education in the Arab states of the Gulf and the attitudes and aspirations of young women towards higher education. She is interested in the social function higher education plays in society.

\section{Notes}

1. The budget allocated for higher and university education is estimated at 3.4 billion dirhams (342 million U.S. dollars), which is $6.92 \%$ of the total budget (Ministry of Education, 2015).

2. Emiratization is an initiative by the government of the United Arab Emirates to enhance job opportunities for UAE nationals in both public and private job sectors (https://u.ae/ en/information-and-services/jobs/vision-2021-and-emiratisation/emiratisation-).

3. Clash of civilizations theorizes that conflict in international relations increasingly would be due to clashes between civilizations rather than to ideology or economic interests (https://www.oxfordreference.com/view/10.1093/oi/authority.20110803095615670).

4. This statistic is from 2014.

5. In Islam, an imam is a religious leader of a Muslim community and/or the person who leads the prayers in a mosque (Collins, n.d.). 


\section{References}

[1] Alhejji, H, \& Garavan, T. (2016). Human Resource Development in Middle East. Edited by Thomas N. Garavan, Alma M. McCarthy, Michael J. Morley, Global Human Resource Development Regional and Country Perspectives. Routledge. https://doi.org/10.4324/9781315818177

[2] Alwedinani, J. (2016). Gender and subject choice in higher education in Saudi Arabia. Unpublished dissertation. https://core.ac.uk/download/pdf/77023811.pdf

[3] Amano, I. (1983). The function of higher education: Status expression. The Japan Society of Educational Sociology, 38, 44-49 (Japanese). www.jstage.jst.go.jp

[4] AONHewitt (2012). Qudurat: A pioneering research study by AonHewitt Middle East. http://www.aon. com/middle-east/attachments/AH-Qudurat-Report-English.pdf

[5] AONHewitt (2013). Understanding the workforce of the future in the UAE. http://tecomgroup.ae/wp-content/uploads/knowledge-library/ DIAC-Understanding-the-Workforce-of-the-Future-in-the-UAE.pdf

[6] Azmat, G., \& Guell, M. \& Manning, A. (2004). Gender gaps in unemployment rates in OECD countries. http://eprints.Ise.ac.uk/19995/1/Gender_Gaps_in_Unemployment_Rates_in_OECD_Countries.pdf

[7] Baki, R. (2004). Gender-segregated education in Saudi Arabia: Its impact on social norms and the Saudi labor market. Education Policy Analysis Archives, 12 (28), 1-12. https://doi.org/10.14507/epaa.v12n28. 2004

[8] Beblawi, H., \& Luciani, G. (1987) The rentier state. London: Croom Helm. https://doi.org/10.4324/ 9781315684864

[9] Bhayani, A. (2014). The market route to higher education in UAE: its rationales and implications. Int Rev Public Nonprofit Mark 11, 75-87. https://doi.org/10.1007/s12208-013-0108-6

[10] Carnevale, A. P., Cheah, B., \& Rose, S. J., (2011). The College Payoff: Education, Occupations, Lifetime Earnings. Executive Summary. Georgetown University's Center on Education and the Workforce. https: //cew.georgetown.edu/cew-reports/the-college-payoff/

[11] Chaoul, H. (2013). Arab Youth Unemployment. Alkhabeer Capital. https://www.jeg.org.sa/sites/default/ files/library/files/2433.pdf

[12] Choi, S. (2016, December 16). A job is the reason for University (Korean). Daenamu. http://www. daenamu.kr/news/articleView.html?idxno=1316

[13] Collins Dictionary (n.d.). Imam. In COBUILD Advanced English Dictionary. https://www.collinsdictionary. com/dictionary/english/imam

[14] Collins, R. (1971). Functional and conflict theories of educational stratification. American Sociological Review, 36(6), 1002-1019. American Sociological Association. http://www.jstor.org/stable/2093761

[15] Collins, R. (1979). The credential society: A historical sociology of education and stratification. Academic Press. https://doi.org/10.7312/coll19234

[16] Department of Economic Development (2016). Abu Dhabi Competitiveness Report 2016. https://added. gov.ae/-/media/Project/TAMM/DED/Publications/Abu-Dhabi-Competitive-Report_English_1410.pdf

[17] Dore, R. P. (1976). The diploma disease: Education, qualification and development. University of California Press. https://doi.org/10.1163/15685217-90007202

[18] Dubai Women Establishment (2009). Arab women readership outlook 2009-2011 $1^{\text {st }}$ Edition. Dubai Women Establishment. https://www.pwc.com/gx/en/women-at-pwc/assets/ arab-women-leadership-outlook.pdf

[19] Dubai Women Establishment (2012). Women Perspective on Work and Political Participation, Social Media, Poll Analysis Report 2012. http://www.dwe.gov.ae/data2/new-poll

[20] Dudovskiy, J. (2018). The Ultimate Guide to Writing a Dissertation in Business Studies: A Step by-Step Assistance. Research Methodology. https://research-methodology.net/about-us/ebook/

[21] El-Temtamy, O., O’Neill, K. \& Midraj, S. (2016). Undergraduate employability training and employment: A UAE study. Higher Education, Skills and Work-based Learning, 6(1), 100-115. https://doi.org/10.1108/ HESWBL-02-2015-0006

[22] EY (2015). How will the GCC close the skills gap? https://www.ey.com/ Publication/vwLUAssets/ey-how-will-the-gcc-close-the-skills-gap/protectlTUltextdollarFILE/ ey-how-will-the-gcc-close-the-skills-gap.pdf

[23] Federal Reserve Bank of Atlanta. (2015). The ZPOP Ratio: A Simple Take on a Complicated Labor Market. http://macroblog.typepad.com/macroblog/2015/09/ the-zpop-ratio-a-simple-take-on-a-complicated-labor-market.html

[24] Findlow, S. (2007). Women, higher education and social transformation in the Arab Gulf. In C. Brock \& Z. L. Levers (Eds.), Aspects of education in the Middle East and Africa (pp. 57-76). Symposium Books. 
[25] Gonzalez, G., Karoly, L., Constant, L., Salem, H., \& Goldman, C. (2008). Facing human capital challenges of the 21st century: Education and labor market Initiatives in Lebanon, Oman, Qatar, and the United Arab Emirate. Land-Qatar policy Institute.

[26] International Labor Organization. (2015). World employment social outlook. http://www.ilo.org/wcmsp5/ groups/public/@dgreports/@dcomm/@publ/documents/publication/wcms_337069.pdf

[27] International Monetary Fund (2015). IMF country report No.15/220 United Arab Emirates. https://www imf.org/external/pubs/ft/scr/2015/cr15220.pdf

[28] Jelili, R. (2010). The Arab Region's unemployment problem revisited, API Working Paper Series. http: //www.arab-api.org/images/publication/pdfs/300/300_wps1015.pdf

[29] Kabbani, N., \& Kothari, E. (2005). Youth employment in the MENA region: A situational assessment. http://siteresources.worldbank.org/SOCIALPROTECTION/Resources/SP-Discussion-papers/ Labor-Market-DP/0534web.pdf

[30] Kropf, A., \& Ramady, M. (Eds.). (2015). Employment and Career Motivation in the Arab Gulf States: The Rentier Mentality Revisited. Gerlach Press.

[31] Mahdi, K. (1997). Some economic aspects of higher education in the Arab Gulf. In Shaw, K., Ed., Higher Education in the Gulf: Problems and Prospects, 19-41.

[32] Ministry of Education (2015). Ministerial Cabinet approves 2015 budget and allocates 3.4 billion dirhams for higher education. http://www.mohesr.gov.ae/En/MediaCenter/News/Pages/ UAE-Cabinet-approves-budget-for-2015-and-allocates-.aspx

[33] Ministry of Higher Education and Scientific Research. (2015). Allocated Budget for Education in $2015 . \quad$ http://www.mohesr.gov.ae/En/MediaCenter/News/Pages/ UAE-Cabinet-approves-budget-for-2015-andallocates-.aspx

[34] Modarress, B., Ansari, A., \& Lockwood, D., (2013). Emiratization: From policy to implementation, International Journal of Human Resources Development and Management 13(2), 188-205. http: //dx.doi.org/10.1504/IJHRDM.2013.055395

[35] OECD (2012). Gender Equality in Education, Employment and Entrepreneurship: Final Report to the MCM 2012. https://www.oecd.org/employment/50423364.pdf

[36] OECD (2016). Unemployment rate (indicator). http://doi.org/10.1787/997c8750-en

[37] Scott-Jackson, W., Kariem, B., Porteous, A. \& Hab, A. (2010). Maximising women's participation in the GCC workforce. Gulf Strategic Consulting. http://www.academia.edu/554086/Maximising_Womens_ participation_in_the_GCC_workforce

[38] Ridge, N. (2014). Education and the reverse gender divide in the Gulf States: Embracing the global, ignoring the local. Teachers College Press.

[39] Shihab, M. (2001). Economic Development in the UAE. In I. Al Abed \& P. Hellyer (Eds.), United Arab Emirates: A New Perspective (pp. 249-259). Trident Press Ltd.

[40] Shin, J., Hwang, K. \& Jo, M. (2015). The Youth Panel 2007 (Korean). Kore Employment Information service. http://www.alio.go.kr/download.dn?fileNo=2335849

[41] Sim, W. (2016). The Educational Aspirations of Saudi Arabian Youth: Implications for Creating a New Framework to Explain Saudi Arabian Society. FIRE: Forum for International Research in Education, 3(2). http://dx.doi.org/10.18275/fire201603021081

[42] Spence, M. A. (1973). Job market signaling. The Quarterly Journal of Economics, 87(3), 355-374. http://www.jstor.org/stable/1882010

[43] Trask, B. (2003). Woman's Issues Worldwide the Middle East and North Africa, Greenwood Press.

[44] United Arab Emirates Ministry of Education, Federal Competitiveness and Statistics Authority. (2018). Statistics by subject. https://fcsa.gov.ae/en-us/Pages/Statistics/Statistics-by-Subject.aspx

[45] United Arab Emirates Ministry of Education. (2018). List of licensed institutions in UAE. https://www. moe.gov.ae/En/MediaCenter/News/Pages/licensedInstitutions.aspx

[46] UAE Labours. (2016). UAE Salary Range \& Pay Scale in 2016. https://uaelabours.blogspot.com/2016/ 08/Salary-average-in-uae6.html

[47] The World Bank Data. (2020). International Labour Organization. ILOSTAT database. https://data. worldbank.org/indicator/.

[48] Yamada, R. (2007). Comparative Analysis of College Students based on Affective and Cognitive Assessment (Japanese). Report of the Grant-in-Aid for Scientific Research(B) (No.16330168).

[49] Young, K. (2016). Women's Labor Force Participation Across the GCC. http://www.agsiw.org/wp-content/ uploads/2016/12/Young_Womens-Labor_ONLINE-2.pdf

[50] Zeffane, R., \& Kemp, L. J. (2012). Emiratization: challenges of strategic and radical change in the United Arab Emirates. In T. Dundon \& A. Wilkinson (Eds.), Case Studies in Global Management Strategy, Innovation and People Management (pp. 306-314). Tilde University Press. 


\section{Appendix A: Major in university and desired future career}

\section{Table A1}

Major in university and desired future career of Emirati women

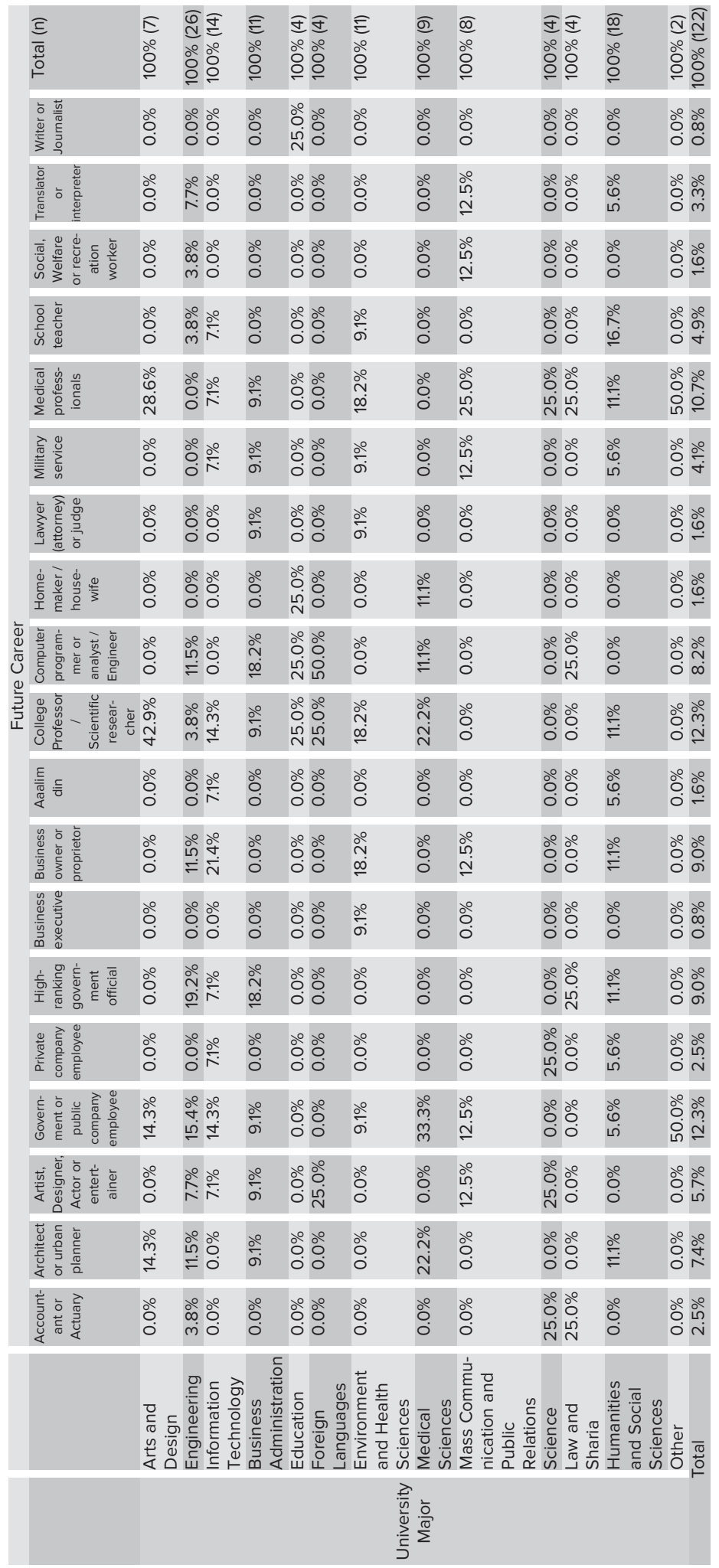

